\section{Histochemistry today: Detection and location of single molecules}

\section{Carlo Pellicciari}

Department of Biology and

Biotechnology, University of Pavia, Italy

\section{Abstract}

Especially in the latest years, histochemical investigations have progressively been oriented toward the visualization and quantitative assessment of single molecules, thanks to the availability of stains, reactions and procedures allowing to detect in situ proteins, or carboydrates or nucleic acid sequences with high specificity. This is evident from the recent literature, where in the large majority of the published articles immunohistochemistry, lectin histochemistry or fluorescence in situ hybridization were used as experimental methodologies. Since in biomedical research it is crucial to specifically label and localize molecules there, where they exert their structural roles and activities, histochemistry will continue to provide scientists the most appropriate tools for tracing molecular maps suitable for reaching a mechanistic explanation of cell functions in tissues.

\section{Introduction}

During the last 150 years, histochemistry has acquired and still maintains importance as a branch of science aimed at identifying and locating chemical components in situ, inside tissues and cells. A great number of histochemical procedures have been invented along this time-span to label specific chemical groups giving rise to final reaction products visible at light or electron microscopy.

Especially at the beginning of the histochemical history, the use of specific (often preferential) stains allowed to identify the composition of tissues in terms of large categories of chemical constituents (proteins, polysaccharides, nucleic acids, lipids). Expectedly, the results of those histochemical investigations provided essentially static descriptions, being anyway essential to offer fundamental information of the structural organization of tissues in the different organs, under healthy and pathological conditions. Even the histochemical reactions which enabled to stain with high specificity a given chemical group (such as the aldehyde or sulfhydryl group) were actually unable to identify single molecular species among the several ones exhibiting such groups. However, already during the first half of the last century, two milestones were established toward the identification in situ of specific molecules: the Feulgen reaction for DNA and the application of fluorescently labelled antibodies as histochemical tools. The first one, ${ }^{1}$ which (in the words of Frederick H. Kasten) ${ }^{2}$ "may be regarded as the first truly histochemical reaction", paved the way to a vast literature on quantitative cytochemistry for the assessment of DNA content in normal and pathological tissues by microphotometry, while immunohistochemistry $^{3}$ has probably become the most widely used approach in basic and applied histochemistry to label definite antigens through a variety of fluorochrome- or enzyme-conjugated, or electron-dense markers, and by different detecting systems. Then, in 1969, MaryLou Pardue and Joseph G. Gall ${ }^{4,5}$ developed the technique of radioactive in situ hybridization, whose application became wider and wider after the introduction of non-radioactive probes. $^{6-8}$ In the early 1970s, fluorochrome-labeled lectins were first used to selectively recognize specific carbohydrate structures in formalin-fixed paraffin- or resin-embedded sections (reviewed by Stoddart and Jones and by Brooks), ${ }^{9,10}$ thus opening the way to a detailed mapping of the sugar structures in tissues with a much more accurate molecular resolution than the traditional Alcian blue or periodic acid-Schiff stain.

\section{Histochemistry of single molecules}

The availability of stains, reactions and procedures allowing to detect in situ proteins, or carboydrates or nucleic acid sequences with high specificity progressively oriented the histochemical investigations toward the visualization and quantitative assessment of single molecules; especially in recent years, this is obvious, looking at the recently published histochemical books ${ }^{11,12}$ and scientific articles. During the last ten years, about 350,000 papers have been published in qualified journals (according to the Scopus database) concerning the application of histochemical techniques on a wide and multiform variety of subjects, from cell and tissue biology in animal and plant organisms, to human and animal pathology, microbiology, experimental and reconstructive medicine, nanotechnology and so forth. Most of these articles were
Correspondence: Carlo Pellicciari, Dipartimento di Biologia e Biotecnologie "Lazzaro Spallanzani" Università degli Studi di Pavia, via A. Ferrata 9, 27100 Pavia, Italy. E-mail: carlo.pellicciari@unipv.it

Key words: Basic and applied histochemistry; single molecules detection; histochemical methods.

Received for publication: 20 December 2017. Accepted for publication: 21 December 2017.

This work is licensed under a Creative Commons Attribution-NonCommercial 4.0 International License (CC BY-NC 4.0).

CC Copyright C. Pellicciari, 2017

Licensee PAGEPress, Italy

European Journal of Histochemistry 2017; 61:2885 doi:10.4081/ejh.2017.2885

published in non-histochemical journals in the biological and medical field, which demonstrates that non-histochemist scientists widely apply histochemical procedures in their researches. ${ }^{13}$ In about $90 \%$ of these articles, immunohistochemistry, fluorescence in situ hybridization or lectin histochemistry were used as experimental methodologies.

Consistently, in the last three years, more than $85 \%$ of the articles published in the European Journal of Histochemistry reported on investigations performed by these techniques, whereas they were less than $60 \%$ fifteen years ago. This journal publishes papers on functional cell and tissue biology in animals and plants, with attention to differentiation and development, cell-cell interaction, molecular trafficking and cellular bases of diseases; thus, it may provide a reasonably reliable outline of a large assortment of research subjects where histochemistry was chosen as the major experimental approach.

In almost all the articles on tumors in humans and animals, immunohistochemistry was used in the attempt either to define diagnostic/prognostic marker proteins ${ }^{14-19}$ or to elucidate at the molecular level the process of carcinogenesis or tumor development; ${ }^{20-23}$ an altered or ectopic expression of specific proteins was often found to characterize organs or cells also in non-tumor diseases. $^{24-32}$

The effects of different pharmacological or physical treatments on the expression of intracellular or extracellular matrix proteins have been investigated in several articles $^{33-41}$ where immunohistochemistry was mostly used to relate the morphofunctional 
changes observed in different model systems in vitro or in vivo with the activation of specific molecular pathways.

Several papers were aimed at illustrating the tissue organization and protein expression of still poorly described organs from various Vertebrate and Invertebrate species:42-54 here, the morphological description of the microanatomical and histological features was paralleled by the detection of specific molecules responsible for the tissue functional characteristics, also as a consequence of seasonal dynamic changes. ${ }^{55-57}$

The immunolabeling of marker proteins was extensively applied in studies aimed at distinguishing stem/progenitor cells or at elucidating the process of cell differentiation and morphogenesis during pre- and post-natal development in mammals, including humans, ${ }^{58-76}$ with special attention to the nervous system, ${ }^{65,66}$ sensory organs, ${ }^{67-69}$ skin, ${ }^{70}$ lung, ${ }^{70,71}$ and the skeletal apparatus. ${ }^{72-75}$ Also in plants, the histochemical detection and localization of particular substances (namely alkaloids and acetogenins) in the endosperm proved to be significant to describe the process of seedling development. ${ }^{76,77}$

Several articles have recently been published in the European Journal of Histochemistry on new methods or novel applications of well-established microscopical or histochemical techniques. ${ }^{78-98}$ Some of them were intended to improve fixation, embedding and antigen-retrieval procedures for protein immunodetection, with an obvious interest for the techniques suitable for aldehyde-fixed/paraffin-embedded samples, ${ }^{82-86}$ which allows to extend the use of histochemical reactions to archived samples. A group of papers ${ }^{90-93}$ were focused on the acquisition and interpretation of autofluorescence spectra from unprocessed biological tissues in vivo and ex vivo. In fact, under appropriate light excitation several molecular components (such as collagen and elastin, porphyrin derivatives, fatty acids, vitamin A, lipofuscins, NAD(P)H and flavins) act as endogenous fluorophores emitting in the UV-visible to near-IR spectral range, and may be used as intrinsic biomarkers to monitor the biological substrate conditions. The structural organization and the metabolic conditions of tissues and cells affect the amount, the distribution and the microenvironmental state of the endogenous fluorophores, with consequent changes in their fluorescence emission properties: the appropriate analysis and interpretation of tissue autofluorescence spectra may thus provide a powerful tool to identify even minute changes in the meta- bolic properties of cells and tissues, ${ }^{94}$ with great diagnostic potential in medicine through the so-called optical biopsy.

Raman microspectroscopy was employed for demonstrating that hydroxyapatite, cholesterol, and carotenoids colocalize in calcified stenotic aortic valves, ${ }^{95}$ while Energy Dispersive X-ray (EDX) microanalysis through transmission electron microscopy was used to trace the presence of asbestos nanofibers in histological preparations. ${ }^{96}$

Fluorescence microscopy and electron microscopy after diaminobenzidine photooxidation were used to demonstrate the intracellular distribution of calcium ions ${ }^{96}$ or to visualize the intracellular fate of nanoparticles used as drug carriers. ${ }^{98,99}$

\section{Concluding remarks}

In 1953, A.G. Everson Pearse wrote in the Postgraduate Medical Journal that "the importance of histochemistry for the many cytologists, histologists and pathologists who wish to use its techniques lies in the fact that it offers an escape from static descriptive types of research into problems bearing on the behaviour of tissues and allows a dynamic and functional approach to normal cytology as well as to cellular pathology". ${ }^{100}$ After more than sixty years, this statement is still up-to-date, and histochemical investigations are more and more addressed to identify single molecules to correlate chemical composition and physiology, and to understand the molecular bases of the dynamic changes which occur in healthy and pathological tissues.

It is generally agreed that cellular functions depends not only on the occurrence of specific molecules but also on their precise cytosolic, nuclear or organelle location. Consequently, in biomedical research it is crucial to specifically label and localize molecules there, where they exert their structural roles and activities. Thanks to the progress of super-resolution microscopy, it is nowadays possible to obtain multicolor fluorescence images at the nanoscale, with a resolution comparable to electron microscopy: ${ }^{101-103}$ no doubt, histochemistry will continue to provide scientists the most appropriate tools for precisely tracing molecular maps in the attempt to get a mechanistic explanation of the "behaviour" of cells in tissues.

\section{References}

1. Feulgen R, Rossenbeck $\mathrm{H}$ Mikroskopisch-chemischer Nachweis einer Nucleinsaure von Typus der Thymonucleinsaure und die darauf beruhende elective Farbung von Zellkernen in Mikroskopischer Praparaten. Hoppe Seyler's Z Physiol Chem 1924;135:203-48.

2. Kasten FH. Robert Feulgen and his histochemical reaction for DNA. Biotech Histochem 2003;78:1;45-9.

3. Coons AH: Fluorescent antibodies as histochemical tools. Fed Proc 1951; 10:558-9.

4. Gall JG, Pardue ML. Formation and detection of RNA-DNA hybrid molecules in cytological preparations. Proc Natl Acad Sci USA 1969;63:378-83.

5. Pardue ML, Gall JG. Molecular hybridization of radioactive DNA to the DNA of cytological preparations. Proc Natl Acad Sci USA 1969;64:600-4.

6. Rudkin GT, Stollar BD. High resolution of DNA-RNA hybrids in situ by indirect immunofluorescence. Nature 1977;265: 472-4.

7. Langer-Safer PR, Levine M, Ward DC. Immunological method for mapping genes on Drosophila polytene chromosomes. Proc Natl Acad Sci USA 1982;79:4381-5.

8. Durrant I. Nonradioactive in situ hybridization for cells and tissues. In: Harwood A.J. (Editor) Basic DNA and RNA Protocols. Methods Mol Biol 1996;58:155-67.

9. Stoddart RW, Jones CJ. Lectin histochemistry and cytochemistry-light microscopy: avidin-biotin amplification on resin-embedded sections. Methods Mol Med 1998;9:21-39.

10. Brooks SA. Lectin histochemistry: Historical perspectives, state of the art, and the future. Methods Mol Biol 2017;1560:93-107.

11. Exbrayat J-M (Editor). Histochemical and cytochemical methods of visualization. CRC Press; Boca Raton; 2013.

12. Pellicciari C, Biggiogera M (Editors). Histochemistry of single molecules: Methods and protocols. Methods in molecular biology. Vol. 1560. Humana Press; New York; 2017.

13. Pellicciari C. Histochemistry in biology and medicine: a message from the citing journals. Eur J Histochem 2015;59:2610.

14. Fantinato E, Milani L, Sironi G. Sox9 expression in canine epithelial skin tumors. Eur J Histochem 2015;59: 2514 . 
15. Guerriero E, Capone F, Accardo M, Sorice A, Costantini M, Colonna G, et al. GPX4 and GPX7 over-expression in human hepatocellular carcinoma tissues. Eur J Histochem 2015;59: 2540 .

16. Waisberg J, Theodoro TR, Matos LL, Orlandi FB, Serrano RL, Saba GT, et al. Immunohistochemical expression of heparanase isoforms and syndecan-1 proteins in colorectal adenomas. Eur J Histochem 2016;60:2590.

17. Sferra R, Pompili S, Festuccia C, Marampon F, Gravina GL, Ventura L, et al. The possible prognostic role of histone deacetylase and transforming growth factor $\beta /$ Smad signaling in high grade gliomas treated by radiochemotherapy: a preliminary immunohistochemical study. Eur J Histochem 2017;61:2732

18. F, Castelnuovo P, Capella C, Porta G. OTX1 and OTX2 as possible molecular markers of sinonasal carcinomas and olfactory neuroblastomas. Eur J Histochem 2017;61:2730.

19. Fanni D, Manchia M, Lai F, Gerosa C, Ambu R, Faa G. Immunohistochemical markers of CYP3A4 and CYP3A7: a new tool towards personalized pharmacotherapy of hepatocellular carcinoma. Eur J Histochem 2016;60:2614

20. Caocci G, Greco M, Fanni D, Senes G, Littera R, Lai S, et al. HLA-G expression and role in advanced-stage classical Hodgkin lymphoma. Eur J Histochem 2016;60:2606.

21. Costa YF, Tjioe KC, Nonogaki S, Soares FA, Pereira Lauris JR, et al. Are podoplanin and ezrin involved in the invasion process of the ameloblastomas? Eur J Histochem 2015;59: 2451.

22. Cioca A, Ceausu AR, Marin I, Raica M, Cimpean AM. The multifaceted role of podoplanin expression in hepatocellular carcinoma. Eur J Histochem 2017; 61:2707.

23. Chen W, Liang J, Huang L, Cai J, Lei Y, Lai J, et al. Characterizing the activation of the Wnt signaling pathway in hilar cholangiocarcinoma using a tissue microarray approach. Eur J Histochem 2016;60:2536.

24. Janiuk I, Kasacka I. Quantitative evaluation of CART-containing cells in urinary bladder of rats with renovascular hypertension. Eur J Histochem 2015; 59: 2446.

25. Loreto C, Psaila A, Musumeci G, Castorina S, Leonardi R. Apoptosis activation in human carious dentin.
An immunohistochemical study. Eur J Histochem 2015;59:2513.

26. Di Vito A, Scali E, G Ferraro, Mignogna C, Presta I, Camastra C, et al. Elastofibroma dorsi: a histochemical and immunohistochemical study. Eur J Histochem 2015;59:2459.

27. Goteri G, Altobelli E, Tossetta G, Zizzi A, Avellini C, Licini C, et al. High temperature requirement A1, transforming growth factor betal, phosphoSmad2 and Ki67 in eutopic and ectopic endometrium of women with endometriosis. Eur J Histochem 2015; 59:2570.

28. Leonardi R, Perrotta RE, Loreto C, Musumeci G, Crimi S, Dos Santos JN, et al. Toll-like receptor 4 expression in the epithelium of inflammatory periapical lesions. An immunohistochemical study. Eur J Histochem 2015;59: 2547.

29. Vetuschi A, D'Alfonso A, Sferra R, Zanelli D, Pompili S, Patacchiola F, et al. Changes in muscularis propria of anterior vaginal wall in women with pelvic organ prolapse. Eur J Histochem 2016;60:2604.

30. Al-dhohorah T, Mashrah M, Yao Z, Huang J. Aberrant DKK3 expression in the oral leukoplakia and oral submucous fibrosis: a comparative immunohistochemical study. Eur J Histochem 2016;60:2629.

31. Carotti S, Perrone G, Amato M, Vespasiani Gentilucci U, Righi D, Francesconi M, et al. Reelin expression in human liver of patients with chronic hepatitis C infection. Eur J Histochem 2017;61:2745.

32. Merigo F, Boschi F, Lasconi C, Benati D, Sbarbati A. Molecules implicated in glucose homeostasis are differentially expressed in the trachea of lean and obese Zucker rats. Eur J Histochem 2016;60:2557.

33. Okamoto K, Kiga N, Shinohara Y, Tojyo I, Fujita S. Effect of interleukin1 beta and dehydroepiandrosterone on the expression of lumican and fibromodulin in fibroblast-like synovial cells of the human temporomandibular joint. Eur J Histochem 2015;59: 2440 .

34. Frontalini F, Curzi D, Giordano FM, Bernhard JM, Falcieri E, Coccioni R. Effects of lead pollution on Ammonia parkinsoniana (foraminifera): ultrastructural and microanalytical approaches. Eur J Histochem 2015; 59:2460.

35. Di Nisio C, Zizzari VL, S Zara, Falconi $\mathrm{M}$, Teti $\mathrm{G}$, Tetè $\mathrm{G}$, et al.
RANK/RANKL/OPG signaling pathways in necrotic jaw bone from bisphosphonate-treated subjects. Eur J Histochem 2015;59:2455.

36. Costanzo M, Cisterna B, Vella A, Cestari T, Covi V, Tabaracci G, et al. Low ozone concentrations stimulate cytoskeletal organization, mitochondrial activity and nuclear transcription. Eur J Histochem 2015;59:2515.

37. Ferreira M Jr, Batista SA, Vidigal PVT, Cordeiro AAC, Oliveira FMS, Prata LO, et al. Infection with CagApositive Helicobacter pylori strain containing three EPIYA C phosphorylation sites is associated with more severe gastric lesions in experimentally infected Mongolian gerbils (Meriones unguiculatus). Eur J Histochem 2015;59:2489.

38. Cutroneo G, Vermiglio G, Centofanti A, Rizzo G, Runci M, Favaloro A, et al. Morphofunctional compensation of masseter muscles in unilateral posterior crossbite patients. Eur J Histochem 2016;60:2605.

39. Verderame M, Limatola E, Scudiero R. Metallothionein expression and synthesis in the testis of the lizard Podarcis sicula under natural conditions and following estrogenic exposure. Eur J Histochem 2017;61:2777.

40. Giacoppo S, Gugliandolo A, Trubiani O, Pollastro F, Grassi G, Bramanti P, et al. Cannabinoid CB2 receptors are involved in the protection of RAW264.7 macrophages against the oxidative stress: an in vitro study. Eur J Histochem 2017;61:2749.

41. Favorito R, Monaco A, Grimaldi MC, Ferrandino I. Effects of cadmium on the glial architecture in lizard brain. Eur J Histochem 2017;61:2734.

42. Strobel S, Encarnação JA, Becker NI, Trenczek TE. Histological and histochemical analysis of the gastrointestinal tract of the common pipistrelle bat (Pipistrellus pipistrellus). Eur J Histochem 2015;59:2477.

43. Zhang H, Guo X, Zhong S, Ge T, Peng $\mathrm{S}$, Yu P, et al. Heterogeneous vesicles in mucous epithelial cells of posterior esophagus of Chinese giant salamander (Andrias davidianus). Eur $\mathrm{J}$ Histochem 2015;59:2521.

44. Cutroneo G, Centofanti A, Speciale F, Rizzo G, Favaloro A, Santoro G, et al. Sarcoglycan complex in masseter and sternocleidomastoid muscles of baboons: an immunohistochemical study. Eur J Histochem 2015;59:2509.

45. Seliverstova EV, Prutskova NP. Receptor-mediated endocytosis of 
lysozyme in renal proximal tubules of the frog Rana temporaria. Eur J Histochem 2015;59:2482.

46. Zhang H, Yu P, Zhong S, Ge T, Peng S, Zhou Z, Guo X. Gliocyte and synapse analyses in cerebral ganglia of the Chinese mitten crab, Eriocheir sinensis: ultrastructural study. Eur J Histochem 2016;60:2655.

47. Torres-da-Silva KR, Da Silva AV, Barioni NO, Tessarin GW, De Oliveira JA, Ervolino E, et al. Neurochemistry study of spinal cord in non-human primate (Sapajus spp.). Eur J Histochem 2016;60:2623.

48. Úbeda-Manzanaro M, Ortiz-Delgado JB, Sarasquete C. The Bromodomain testis-specific gene (Brdt) characterization and expression in gilthead seabream, Sparus aurata, and European seabass, Dicentrarchus labrax. Eur J Histochem 2016;60: 2638.

49. Yasui T, Gomi H, Kitahara T, Tsukise A. Ultrastructure and immunohistochemical characterization of proteins concerned with the secretory machinery in goat ceruminous glands. Eur J Histochem 2017;61:2828.

50. Porzionato A, Rucinski M, Macchi V, Sarasin G, Malendowicz LK, De Caro R. ECRG4 expression in normal rat tissues: expression study and literature review. Eur J Histochem 2015;59: 2458.

51. Zhang Y, Wang J, Cheng X, Yi B, Zhang X, Li Q. Apigenin induces dermal collagen synthesis via $\operatorname{smad} 2 / 3$ signaling pathway. Eur J Histochem. 2015;59:2467.

52. Cobo T, Obaya A, Cal S, Solares L, Cabo R, Vega JA, et al. Immuno-histochemical localization of periostin in human gingiva. Eur J Histochem 2015;59:2548.

53. Fede C, Albertin G, Petrelli L, Sfriso MM, Biz C, De Caro R, et al. Expression of the endocannabinoid receptors in human fascial tissue. Eur J Histochem 2016;60:2643.

54. Mangas A, Yajeya J, González N, Duleu S, Geffard M, Coveñas R. NOtryptophan: a new small molecule located in the rat brain. Eur J Histochem 2016;60:2692.

55. Zhang H, Wang Y, Zhang J, Wang L, Li Q, Sheng X, et al. Testicular expression of NGF, TrkA and p75 during seasonal spermatogenesis of the wild ground squirrel (Citellus dauricus Brandt). Eur $\mathrm{J}$ Histochem 2015;59:2522.

56. Li Q, Zhang F, Zhang S, Sheng X,
Han X, Weng Q, et al. Seasonal expression of androgen receptor, aromatase, and estrogen receptor alpha and beta in the testis of the wild ground squirrel (Citellus dauricus Brandt). Eur J Histochem 2015;59: 2456.

57. Zhang F, Wang J, Jiao Y, Zhang L, Zhang $\mathrm{H}$, Sheng $\mathrm{X}$, et al. Seasonal changes of androgen receptor, estrogen receptors and aromatase expression in the medial preoptic area of the wild male ground squirrels (Citellus dauricus Brandt). Eur J Histochem 2016; 60:2621.

58. Miko M, Danišovič L, Majidi A, Varga I. Ultrastructural analysis of different human mesenchymal stem cells after in vitro expansion: a technical review. Eur J Histochem 2015;59: 2528.

59. Escobar ML, Echeverría OM, García G, Ortíz R, Vázquez-Nin GH. Immunohistochemical and ultrastructural study of the lamellae of oocytes in atretic follicles in relation to different processes of cell death. Eur J Histochem 2015;59:2535.

60. Karaca T, Hulya Uz Y, Karabacak R, Karaboga I, Demirtas S, Cagatay Cicek A. Effects of hyperthyroidism on expression of vascular endothelial growth factor (VEGF) and apoptosis in fetal adrenal glands. Eur J Histochem 2015;59:2560.

61. Aredia F, Malatesta M, Veneroni P, Bottone MG. Analysis of ERK3 intracellular localization: dynamic distribution during mitosis and apoptosis. Eur J Histochem 2015;59:2571.

62. Ambu R, Vinci L, Gerosa C, Fanni D, Obinu E, Faa A, et al. WT1 expression in the human fetus during development. Eur J Histochem 2015;59:2499.

63. Hansson J, Ericsson AE, Axelson H, Johansson ME. Species diversity regarding the presence of proximal tubular progenitor cells of the kidney. Eur J Histochem 2016;60:2567.

64. Melrose J. The knee joint loose body as a source of viable autologous human chondrocytes. Eur J Histochem 2016; 60:2645.

65. Vinci L, Ravarino A, Fanos V, Naccarato AG, Senes G, Gerosa C, et al. Immunohistochemical markers of neural progenitor cells in the early embryonic human cerebral cortex. Eur J Histochem 2016;60:2563.

66. Pibiri V, Ravarino A, Gerosa C, Pintus MC, Fanos V, Faa G. Stem/progenitor cells in the developing human cerebellum: an immunohistochemical study.
Eur J Histochem 2016;60:2686.

67. Liu WJ, Yang J. Preferentially regulated expression of connexin 43 in the developing spiral ganglion neurons and afferent terminals in post-natal rat cochlea. Eur J Histochem 2015;59: 2464.

68. Liu WJ, Yang J. Developmental expression of inositol 1, 4, 5-trisphosphate receptor in the post-natal rat cochlea. Eur J Histochem 2015;59: 2486.

69. Ferretti V, Segal-Eiras Á, Barbeito CG, Croce MV. Muc5ac mucin expression during rat skin development. Eur J Histochem 2015;59:2462.

70. Kato T, Oka K, Nakamura T, Ito A. Decreased expression of Met during differentiation in rat lung. Eur J Histochem 2016;60:2575.

71. Cau F, Pisu E, Gerosa C, Senes G, Ronchi F, Botta C, et al. Interindividual variability in the expression of surfactant protein $\mathrm{A}$ and $\mathrm{B}$ in the human lung during development. Eur J Histochem 2016;60:2678

72. Fujikawa K, Yokohama-Tamaki T, Morita T, Baba O, Qin C, Shibata S. An in situ hybridization study of perlecan, DMP1, and MEPE in developing condylar cartilage of the fetal mouse mandible and limb bud cartilage. Eur J Histochem 2015;59:2553.

73. Di Giancamillo A, Andreis ME, Taini P, Veronesi MC, Di Giancamillo M, Modina SC. Cartilage canals in newborn dogs: histochemical and immunohistochemical findings. Eur J Histochem 2016;60:2701.

74. Carvalho de Moraes LO, Tedesco RC, Arraez-Aybar LA, Klein O, MéridaVelasco JR, Alonso LG. Development of synovial membrane in the temporomandibular joint of the human fetus. Eur J Histochem 2015;59:2569.

75. Zhang H, Liu P, Wang S, Liu C, Jani P, $\mathrm{Lu}$ Y, Qin C. Transgenic expression of dentin phosphoprotein inhibits skeletal development. Eur J Histochem 2016; 60:2587.

76. Laguna Hernández G, Brechú-Franco AE, De la Cruz-Chacón I, GonzálezEsquinca AR. Histochemical detection of acetogenins and storage molecules in the endosperm of Annona macroprophyllata Donn Sm. seeds. Eur J Histochem 2015;59:2502.

77. Brechú-Franco AE, LagunaHernández G, De la Cruz-Chacón I, González-Esquinca AR. In situ histochemical localisation of alkaloids and acetogenins in the endosperm and embryonic axis of Annona macropro- 
phyllata Donn. Sm. seeds during germination. Eur J Histochem 2016;60: 2568.

78. Pellicciari C. Is there still room for novelty, in histochemical papers? Eur J Histochem 2016;60:2758

79. Iachettini S, Valaperta R, Marchesi A, Perfetti A, Cuomo G, Fossati B, et al. Tibialis anterior muscle needle biopsy and sensitive biomolecular methods: a useful tool in myotonic dystrophy type 1. Eur J Histochem 2015;59: 2562.

80. Korzhevskii DE, Sukhorukova EG, Kirik OV, Grigorev IP. Immuno-histochemical demonstration of specific antigens in the human brain fixed in zinc-ethanol-formaldehyde. Eur J Histochem 2015;59:2530.

81. Pinto AJ, de Amorim IF, Pinheiro LJ, Madeira IM, Souza CC, ChiariniGarcia H, et al. Glycol methacrylate embedding for the histochemical study of the gastrointestinal tract of dogs naturally infected with Leishmania infantum. Eur J Histochem 2015;59:2546.

82. Kaneko $\mathrm{Y}$, Onda N, Watanabe $\mathrm{Y}$, Shibutani M. Identification of 5hydroxytryptamine-producing cells by detection of fluorescence in paraffinembedded tissue sections. Eur J Histochem 2016;60:2684.

83. Rieger J, Janczyk P, Hünigen $H$, Plendl J. Enhancement of immunohistochemical detection of Salmonella in tissues of experimentally infected pigs. Eur J Histochem 2015;59:2516.

84. Paulsen IMS, Dimke H, Frische S. A single simple procedure for dewaxing, hydration and heat-induced epitope retrieval (HIER) for immunohistochemistry in formalin fixed paraffinembedded tissue. Eur $\mathbf{J}$ Histochem 2015;59: 2532.

85. Schläfli AM, Berezowska S, Adams O, Langer R, Tschan MP. Reliable LC3 and p62 autophagy marker detection in formalin fixed paraffin embed- ded human tissue by immunohistochemistry. Eur J Histochem 2015;59: 2481.

86. Tabola R, Zaremba-Czogalla $\mathrm{M}$, Baczynska D, Cirocchi R, Stach K, Grabowski K, Augoff K. Fibroblast activating protein- $\alpha$ expression in squamous cell carcinoma of the esophagus in primary and irradiated tumors: the use of archival FFPE material for molecular techniques. Eur J Histochem 2017;61:2793.

87. Rizo-Roca D, Ríos-Kristjánsson JG, Núñez-Espinosa C, Ascensão A, Magalhães J, Torrella JR, et al. A semiquantitative scoring tool to evaluate eccentric exercise-induced muscle damage in trained rats. Eur J Histochem 2015;59:2544.

88. Šoštarić-Zuckermann IC, Severin K Huzak M, Hohšteter M, Gudan Kurilj A, Artuković B, et al. Quantification of morphology of canine circumanal gland tumors: a fractal based study. Eur J Histochem 2016;60:2609.

89. Percival KR, Radi ZA. A modified Verhoeff's elastin histochemical stain to enable pulmonary arterial hypertension model characterization. Eur J Histochem 2016;60:2588.

90. Di Guardo G. Lipofuscin, lipofuscinlike pigments and autofluorescence. Eur J Histochem 2015;59:2485.

91. Sainz BJr, I Miranda-Lorenzo, Heeschen C. The fuss over lipo"fuss"cin: not all autofluorescence is the same. Eur J Histochem 2015; 59:2512

92. Croce AC, Bottiroli G. New light in flavin autofluorescence. Eur J Histochem 2015;59:2576.

93. Croce AC, Bottiroli G. Lipids: Evergreen autofluorescent biomarkers for the liver functional profiling. Eur J Histochem 2017;61:2808.

94. Croce AC, Bottiroli G. Autofluorescence spectroscopy and imaging: a tool for biomedical research and diagnosis. Eur J Histochem 2014;
58:2461.

95. Bonetti A, Bonifacio A, Della Mora A, Livi U, Marchini M, Ortolani F. Carotenoids co-localize with hydroxyapatite, cholesterol, and other lipids in calcified stenotic aortic valves. Ex vivo Raman maps compared to histological patterns. Eur J Histochem 2015;59: 2505

96. Scimeca M, Pietroiusti A, Milano F, Anemona L, Orlandi A, Marsella LT, et al. Elemental analysis of histological specimens: a method to unmask nano asbestos fibers. Eur J Histochem 2016; 60:2573.

97. Poletto V, Galimberti V, Guerra G, Rosti V, Moccia F, Biggiogera M. Fine structural detection of calcium ions by photoconversion. Eur J Histochem 2016; 60: 2695.

98. Malatesta M, Grecchi S, Chiesa E, Cisterna B, Costanzo M, Zancanaro C. Internalized chitosan nanoparticles persist for long time in cultured cells. Eur J Histochem 2015;59:2492.

99. Costanzo M, Carton F, Marengo A, Berlier G, Stella B, Arpicco S, et al. Fluorescence and electron microscopy to visualize the intracellular fate of nanoparticles for drug delivery. Eur $\mathrm{J}$ Histochem 2016;60:2640.

100. Pearse AGE. The place of histochemistry today. Postgrad Med J 1953; 29:536-537.

101. Sahl SJ, Hell SW, Jakobs S. Fluorescence nanoscopy in cell biology. Nat Rev Mol Cell Biol 2017;18:685-701.

102. Schubert V. Super-resolution Microscopy - Applications in plant cell research. Front Plant Sci 2017; 8:531.

103. Hauser M, Wojcik M, Kim D, Mahmoudi M, Li W, Xu K. Correlative Super-resolution Microscopy: New dimensions and new opportunities. Chem Rev. 2017; 117:7428-56. 